\title{
The changing roles of internal auditors in the Ukrainian central government
}

Tamara Volodina Department of Economic Analysis and Accounting, Nord University, Bodo, Norway

Giuseppe Grossi

Department of Economic Analysis and Accounting, Nord University, Bodo, Norway and Department of Business Administration, Nord University, Kristianstad, Sweden, and

Veronika Vakulenko

Department of Economic Analysis and Accounting, Nord University, Bodo, Norway
Changing roles of internal auditors

Received 25 April 2021 Revised 13 October 2021 8 December 2021 Accepted 17 January 2022

\begin{abstract}
Purpose - The purpose of this paper is to explore how internal auditors' (IAs) roles have changed because of the diffusion of neoliberal ideologies in the Ukrainian public sector.

Design/methodology/approach - A qualitative methodological approach was applied. Data were collected from 29 semi-structured interviews with public sector auditors in Ukraine's central government; secondary data analysis was also performed.

Findings - IAs' role in Ukraine's central government has changed significantly, with reforms attempting to move to performance auditing. Consequently, Ukrainian central government IAs appeared in the multi-expectation situation, due to the division of the role senders into two different areas. On one hand, IAs are expected to perform new roles set by the Ministry of Finance of Ukraine, while their traditional role as "watchdogs" is still expected by managers (heads of institutions). Diverging expectations resulted in the role conflict that impedes the change in IAs' role and performance auditing introduction in the Ukrainian central government. Moreover, we identify factors that motivate IAs to prioritise managers' expectations, while trying to cope with the existing role conflict in Ukraine's central government.
\end{abstract}

Originality/value - This study makes a threefold contribution by enriching the understanding of auditors' roles, role conflicts that public sector auditors may experience and factors that influence how auditors cope with such conflicts, through the lenses of role theory; exploring the change in roles with the

(c) Tamara Volodina, Giuseppe Grossi and Veronika Vakulenko. Published by Emerald Publishing Limited. This article is published under the Creative Commons Attribution (CC BY 4.0) licence. Anyone may reproduce, distribute, translate and create derivative works of this article (for both commercial and non-commercial purposes), subject to full attribution to the original publication and authors. The full terms of this licence may be seen at http://creativecommons.org/licences/by/4.0/ legalcode

The authors are indebted to the participants in the CIGAR Workshop (digital event, June 2020), EURAM 2021 Conference (digital event, June 2021), AAEE Conference (Digital event, June 2021), CIGAR Conference and Doctoral Colloquium (Digital events, June 2021), IPA Conference 2021 (Digital event, July 2021), Prof. Lee Parker (RMIT University, Australia), Dr Fredrik Svärdsten (Stockholm University, Sweden), Dr Brynjar Gilberg (Nord University, Norway), the editor of the journal (Prof. Zahirul Hoque) as well as two anonymous reviewers, for their valuable comments on earlier versions of this article. Research financed by Norwegian Research Council, "Transformative Capabilities of Accounting Profession: Study of small and medium accounting practices”, grant ID: 301717.

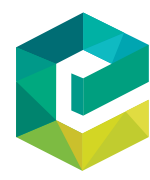

Journal of Accounting \& Organizational Change Vol. 19 No. 6,2023
pp. $1-23$ Emerald Publishing Limited 1832-5912 
JAOC 19,6

emergence of performance auditing; and shedding light on public sector auditing in the less explored context of a post-Soviet country.

Keywords Public audit, Performance auditing, Internal auditor, Role theory, Role conflict, Ukraine

Paper type Research paper

\section{Introduction}

The diffusion of neoliberal ideologies (Lapsley and Miller, 2019), together with the introduction of new public management (NPM), led to a number of public sector changes, including the changes in auditing (Hood, 1995) to uphold the concept of liberty (Ferry and Midgley, 2021). As a result, performance auditing gained increasing prominence worldwide, causing changes in auditors' role (Pollitt, 2003; Barzelay, 1997; Pollitt and Summa, 1996). Besides affecting and contributing to the public sector's effectiveness and efficiency, auditors were now able to look beyond finances to assess government's performance against its own objectives (Pierre et al., 2018). Previous studies showed that auditors possess knowledge and power to promote reforms and help other actors to improve government bodies (Gendron et al., 2001, 2007; Reichborn-Kjennerud and Johnsen, 2018; Morin, 2001).

Performance auditing was widely discussed in academia in connection with NPM (Parker et al., 2018), quality of political and democratic processes (Tillema and ter Bogt, 2010; Morin, 2001), measurement of government performance (Gendron et al., 2007), implementation in different organisations (Barzelay, 1997; Reichborn-Kjennerud and Johnsen, 2018), etc. However, literature on the emerging roles of auditors (Roussy, 2013; Morin and Hazgui, 2016), who were previously perceived as inspectors or "watchdogs" and received a wider spectrum of roles due to the introduction of performance auditing (Roussy, 2013; Morin and Hazgui, 2016), is scarce. Studies on internal auditors' (IAs) role have mainly focused on independence issues (Betti and Sarens, 2021; Ahmad and Taylor, 2009) and IAs' role in good governance development (Roussy, 2013; Barasa, 2015; Ferry et al., 2017). Moreover, possible tensions between IAs' traditional and new roles seem to be overlooked.

The paper aims to fill this research gap by analysing role senders and their expectations, possible role conflicts arising from IAs' changing role in Ukraine's central government and factors which may influence IAs' response to role conflicts. To achieve the research aim, we mobilise role theory (Kahn et al., 1964; Katz and Kahn, 1978) and frame our study around the following research questions:

$R Q 1$. How do heterogeneous role senders' expectations impede IAs' changing role in Ukraine's central government?

RQ2. How does different factors influence the way IAs cope with role conflicts?

The motivation for choosing Ukraine as a research context is conditioned by its transitional institutional context, with several public sector auditing reforms guided by international auditing standards and organisations. The paper focuses on public auditing at the central government level. Methodologically, it is a qualitative case study, for which data was collected from semi-structured interviews with public sector auditors from Ukraine's central government and official documents.

We find that diffusion of neoliberal ideologies and the adoption of NPM instruments in the Ukrainian public sector stimulated the change in IAs' role from that of previously existing revisors or "watchdogs". However, such change created two groups of role senders, divided by their contradictory expectations. On one hand, IAs are expected to perform the new roles set by the Ministry of Finance of Ukraine $(\mathrm{MoF})$, while their traditional role as "watchdogs" is still expected by managers. Consequently, IAs in Ukraine's central government existed in an inter- 
sender role conflict, which impedes their role change. The study also identified several factors which impact IAs' response to the identified role conflict. We show how those factors on three different levels (IAs' experience and knowledge, independence and working environment) influence the way IAs cope with the existing role conflict and motivate them to prioritise the expectations of the second group of role senders (managers).

The remainder of the paper is structured as follows. Section 2 presents a literature overview of the evolution of IAs' roles. Then, role theory is proposed, to deepen the understanding of IAs' roles. Next, the methodological section is outlined, followed by a brief overview of the research context. Further, the empirical section presents the main findings to answer this study's research questions. A discussion on the changing role of IAs in the Ukrainian central government follows, together with conclusions and suggestions for further research.

\section{Roles of public sector auditors}

For purposes of this research, we reviewed public sector auditing literature to collect the existing knowledge on the auditors' role. We present the evolution in role of public sector auditors in general and IAs in particular, underlying causes and consequences of such role change.

Initially, the audit and the "auditor-auditee" interaction did not allow auditors to promote reform, best practice or institutional learning. Auditors' traditional role involves the expression of a definite opinion, through compliance audits or financial statement audits, associated with the "watchdog" role (Roussy, 2013). IAs, likewise, are also traditionally perceived as being confined, to ensure an organisation's records are properly maintained, an assets management system is in place and policies and procedures are properly complied with (Asare, 2008).

Growing interest in performance auditing, as well as the evolution in the roles of public sector auditors in general and IAs in particular, was motivated by the spread of performance measurement and management as part of NPM reform (Romzek, 2000). Auditing started to be used not to ensure prudent spending but, rather, to find a new way of setting the government's administrative priorities and strategies, as well as, ultimately, a new type of government objectives (Power, 1994). According to Power (1994, pp. 4-5), the audit:

$[\ldots]$ is not just a series of (rather uninteresting) technical practices, it must also be understood as an idea [...] that is internal to the ways in which practitioners and policy-makers make sense of what they are doing.

With these public sector reforms, performance auditing, which previously had a narrow scope, primarily focusing on the efficiency of governmental entities, has also changed, gaining a more direct and active role in administrative reform (Barzelay, 1997; Pollitt and Summa, 1996; Pierre et al., 2018). Consequently, auditors underwent a paradigm shift from their traditional practices to performance (value-added) auditing (Aghghaleh et al., 2014; Gørrissen, 2020). As Power (2005) stated, it was largely unthinkable that auditors of the 1960s and 1970s could become agents of change for public sector reform. Today, researchers claim that auditors' much wider new role can contribute significantly to good governance development (Bunn et al., 2018; Morin and Hazgui, 2016; Reichborn-Kjennerud and Johnsen, 2018). Currently, public managers adopt systems and techniques considered to be legitimate, based on their interactions with auditors (Yang, 2021). Auditors possess both performance accountability and facilitation roles, as they move towards at least partial engagement as a stakeholder network collaborator (Pierre and de Fine Licht, 2019; Parker et al., 2021). Consequently, auditors should no longer be perceived as "watchdogs" but, rather, as "agents of change" (Gendron et al., 2001, p. 27), appraisers and modernisers (Ferry and Ahrens, 2021). 
JAOC 19,6

As major financial crises have shown that bookkeeping is not enough (ACCA, 2014; Schillemans et al, 2018, p. 531), the usefulness of internal auditing has yet to be demonstrated (Archambeault et al., 2008). The shift in IAs' roles is also driven by recent disturbances in the internal audit landscape. In a changing business environment, IAs are expected to develop a mindset more oriented towards consultancy or advisory roles, to guide organisations regarding strategic changes (Betti and Sarens, 2021). As skilled advisors, IAs can provide decision-makers with valuable information on how to make decisions (Pearson, 2014). Thus, IAs are, in a sense, a "tool of management" (Schillemans et al., 2018, p. 531) and can also play a crucial role in the accomplishment of one of the most pervasive effects of NPM - the alteration of public servants' ways of thinking, talking and acting (Gendron et al., 2007; Kurunmaki, 1999). In this respect, Nerantzidis et al. (2020) highlight the number of studies on IAs' role in supporting public governance (Roussy, 2013; Barasa, 2015; Ferry et al., 2017) and the relationship of this value of auditing with corporate governance theory (Hay and Cordery, 2018). Therefore, IAs' role has also changed from being a "watchdog" for corporate management to providing a more value-adding strategic service (Deloitte, 2018). IAs now contribute to improving organisational performance by providing support to managers in three ways: by conducting performance audits, through strategic consulting and by taking part in organisational management committees. IAs have clearly "chosen their camp" and operate as members of the management team, rather than the monitoring and oversight team (Roussy, 2013).

To summarise, the development of performance auditing expanded the role of public sector auditors from those of the historically limited "watchdog" or "bookkeeper" into institutional assistants and advisors (Roussy, 2013; Morin and Hazgui, 2016). Therefore, IAs now have a dual focus: taking account of and responding to government priorities and preferences, and the growing concerns with actual outcomes and assessments of effectiveness being exhibited by other groups (Parker et al., 2018). However, such change brings a number of concerns. According to Pollitt (2003) and Morin (2003), multiple auditor roles may not be perfectly correlated with one another. IAs' role in providing audit oversights to their organisation, together with consulting services to management, can cause ongoing role conflict (Ahmad and Taylor, 2009). Consequently, studies demonstrate that auditors struggle to achieve a suitable balance between maintaining independence and objectivity in generating added value by providing advisory and consulting services (Betti and Sarens, 2021; Ahmad and Taylor, 2009; Yang, 2021; Ferry and Ahrens, 2021). IAs were also found to neither address the key risks nor deliver value for the organisations they work for; in other words, normative and practical expectations from IAs may be contradicting each other (Kotb et al., 2020; Christopher, 2019).

Clarity regarding IAs' role is imperative in ensuring their effectiveness (Archambeault et al., 2008). The shift in their roles raises a question not only on IAs' current role but also on the simultaneous existence of multiple roles and possible conflicts that this may cause (Ahmad and Taylor, 2009; Pollitt, 2003; Morin, 2003). Despite significant development in auditing research over the last 20 years (Hay and Cordery, 2021), internal audit function (IAF) in the literature gives an impression of a "jack of all trades, master of none" (Roussy and Perron, 2018). Studies on IAs' role have mainly focused on issues of their independence (Betti and Sarens, 2021; Ahmad and Taylor, 2009) and their part in good governance development (Roussy, 2013; Barasa, 2015; Ferry et al., 2017). However, literature lacks a theoretical explanation of the change in IAs' roles (Roussy, 2013; Morin and Hazgui, 2016), the possible conflicts that this may cause (Van Peursem, 2005; Ahmad and Taylor, 2009; Roussy, 2013; Roussy, 2015) and IAs' response to such conflicts, to clearly capture the role of IAs. Moreover, there is very unbalanced coverage of the range of countries and types of 
auditing included in the research (Hay and Cordery, 2021), and there is a need for evidence on IAs from standalone markets, such as Ukraine (Nerantzidis et al., 2020; Mattei et al., 2021). This research, based on role theory (Kahn et al., 1964; Katz and Kahn, 1978) in Ukraine's central government, will contribute to this gap in the literature with theoretically grounded knowledge on IAs' changing roles.

\section{Insights from role theory}

Role theory is a well-recognised and widely adopted theoretical approach with numerous streams, i.e. functional, symbolic interactionist, structural, organisational and cognitive (Biddle, 1986). For this paper, organisational role theory (Kahn et al., 1964; Katz and Kahn, 1978 ) is used as a relevant basis for empirical studies on the behaviour of individuals (i.e. auditors), aimed at defining their roles in a specific context (Fondas and Stewart, 1994). As IAs operate in a complex and dynamic environment, Katz and Kahn's (1978) role theory might provide novel insights into their roles.

The theory presents the interplay between the focal person (IAs in this study) and role senders (e.g. politicians, international organisations, managers, etc.). The term "role", central to role theory, is defined as a group of tasks that the focal person agrees to perform (Michael, 2001; Liu et al., 2014). Role is attached to institutional position and is part of the division of labour (Wildavsky, 1964). As Rodham (2000, p. 73) stated, it is necessary to look not only at "what they do" but, rather, "why and how do they do what they do." Thus, it is not enough to be aware of IAs' role behaviour; it is also necessary to be mindful of expectations and the way they were transferred to IAs; role senders; factors which may influence the emergence of the specific role of IAs; and possible role stress (in the form of role conflict or role ambiguity). All those are elements of the role set (illustrated in Figure 1) which defines the role of the IAs who received and accepted the specific role set from the role senders.

A key starting point of the role set is expectations. These are evaluative; they set limits and requirements for the focal person (Burkert et al., 2011). Role expectations should not be considered fixed as they "are adjusted in the course of interaction in an evolving dynamic process" (Fondas and Stewart, 1994, p. 90; Taminiau and Heusinkveld, 2017). Expectations are sent to IAs by role senders: those giving orders in the role set (Roussy, 2013). IAs' role is subject to the interactions of the normative expectations of the various interest groups in society with a direct or indirect relationship to the role position, possibly placing IAs in multi-role and multi-expectation situations (Davidson, 1975).

To understand how the specific role is enacted, factors affecting role senders' attitude and IAs' behaviour should also be considered (Lynch, 2007; Wickham and Parker, 2007; Katz and Kahn, 1978). According to role theory, role senders' expectations can be changed

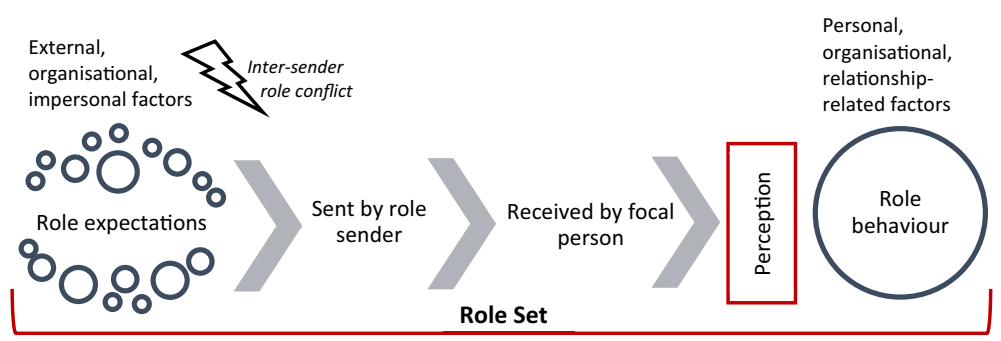

Source: Based on Kahn et al. (1964) and Katz and Kahn (1978)

\section{Changing roles of internal auditors}


JAOC 19,6

dramatically by external, impersonal factors and organisational characteristics (Lynch, 2007; Wickham and Parker, 2007), while IAs' role might also be affected by personal, organisational and relationship-related factors. Roussy (2013) assumed that the legal and regulatory environment would also shape the roles of IAs. Factors also have a relationship with the role ambiguity or role conflict; for instance, IAs' role ambiguity may be decreased through training and changing the organisational structure (Aghghaleh et al., 2014).

Therefore, according to role theory, IAs enact a role to manage a specific situation, as both situation and behaviour are governed by context-specific rules. IAs' perception of the role set, multiple external factors and expectations influence the enactment of the role and may result in role incompatibility between role senders and IAs (Ebimobowei and Kereotu, 2011). This may cause IAs to experience role stress, which can appear in the form of role conflict or role ambiguity.

Role conflict occurs when a focal person is required to perform conflicting roles within an organisation, in other words, receives inadequate needs and abilities from the role senders (Fischer, 2010). Faced with mutually exclusive expectations, the focal person experiences role conflict and cannot make proper judgements about which one to satisfy (Koo and Sim, 1999). When the focal person cannot satisfy all the responsibilities expected by the public, an "expectation gap" appears. There are four different types of role conflict:

(1) intra-sender conflict (incompatible prescriptions and proscriptions from a single role sender);

(2) inter-sender conflict (pressures from different role senders);

(3) inter-role conflict (pressures from different groups of role senders are in conflict); and

(4) person-role conflict (pressures violate the focal person's moral values) (Kahn et al., 1964).

Role ambiguity refers to the discrepancy between the amount of information a person has and the amount required to perform the role adequately. In other words, role ambiguity occurs when there is a lack of information. It is also argued that, even if the focal person knows what to do, they do not always know how to do it (Kahn et al., 1964). Both role conflict and role ambiguity were found to affect IAs' role and result in a decrease in their commitment (Rizzo et al., 1970; Ahmad and Taylor, 2009; Roussy, 2013; Roussy, 2015).

According to Kahn et al. (1964), there are two responses to role stress: behavioural coping efforts and effective symptom formation. The focal person can pick one response or use them in conjunction. Behavioural coping efforts include the focal person's attempts to correspond with expectations or - if impossible - to modify demands. Effective symptom formation leads to highly emotional responses, which sometimes can end in the focal person's complete frustration and dysfunction (Merton, 1949).

The empirical evidence on the main elements of IAs' role set presented by role theory (Kahn et al., 1964; Katz and Kahn, 1978) and illustrated by the authors in Figure 1 will provide us with understanding of the role performed by IAs because of the change in the expectations of role senders in Ukraine's central government. Moreover, role theory offers an explanation for the emergence of role conflicts and different factors that influence the way IAs cope with such conflicts.

\section{Research context}

For many years, Ukrainian public sector auditing was detached from global trends, as a result of the Soviet Union's prolonged influence. Starting from 1992, Ukraine became a 
member-state of the International Monetary Fund (IMF) and a member of the World Bank (WB) and European Bank for Reconstruction and Development (EBRD). Under the influence of those international financial institutions, NPM instruments were introduced as a solution to poor processes, inefficiency and ineffective public services on the road towards political and administrative modernisation of Ukraine's public sector (Dan and Pollitt, 2015). Driven by neoliberal ideologies, accounting and auditing practices received a central role in operationalising the administrative ideas constituting NPM (Power, 1999).

Therefore, changes in Ukraine's public sector had already begun in the period 1991-1997 but were characterised by chaotic reform of both the socio-economic sphere and the state machinery. Considering Ukraine's increasing political instability, the success of such reforms or even their chance of being implemented during this period appeared limited (Bouckaert et al., 2011). Later in 2006, an assessment of Ukrainian public administration was conducted as part of the Support for Improvement in Governance and Management project, with financial support from the United Kingdom Ministry of International Development and the Swedish International Development Agency and the consent of the European Commission (Centre for Adaptation of the Civil Service, 2019).

As a result of international cooperation, Ukraine took the next step towards a European system of public financial control, by developing and implementing the new Budget Code of Ukraine (Verkhovna Rada of Ukraine, 2010; Miedviedkova, 2016). This was adopted as the legal vehicle for the first phase of a public finance reform strategy, adopted in 2007 with the WB's support. Consequently, based on the updated Budget Code, it was expected to modernise budget regulation, develop mutually profitable relations with the IMF and improve the climate for foreign investments in Ukraine (Kraan et al., 2013). Internal audit departments were created with the new wording of Article 26 of the new Budget Code of Ukraine and replaced the "Control-Revision Department" that had functioned in Ukraine since 2000 (Verkhovna Rada of Ukraine, 2010; Order No. 1001). Since 2008, Ukraine has cooperated with the Ministry of Finance of The Netherlands on the further development and improvement of the IAF in Ukraine's central government (MoF, 2019c).

Resulting from the 2014 Association Agreement between Ukraine and the European Union (EU), Ukraine took the next step, cooperating with the EU on the implementation of international standards and public sector improvements. Several key legal instruments concerning internal control and internal auditing in the government were developed during this period. Therefore, the current system is a result of significant changes in public sector policies undergone in Ukraine, due to the intention to join the EU.

Figure 2 visualises key actors in Ukraine's public sector auditing, which includes external and internal auditing, representing parliamentary and governmental financial control. External auditing is represented by the Accounting Chamber of Ukraine (ACU), while its internal counterpart is separated into centralised and decentralised areas. Centralised internal auditing is represented by the MoF, whose activities are directed and coordinated by the Cabinet of Ministers of Ukraine. Decentralised internal auditing is the IAF in central government bodies, organised in Ukraine following the separation of internal control and internal audit departments (De Koning, 1999; Order No. 1001).

The Internal Audit Department interacts with the ACU, head of the institution (manager), audit committee and $\mathrm{MoF}(\mathrm{MoF}, 2019 \mathrm{a})$. According to Article 26, the manager of budget funds (who is head of the institution) forms an independent structural unit of internal audit, which is subordinated and accountable directly to the head of the institution (manager) (Verkhovna Rada of Ukraine, 2010). According to Order No. 1001 and the National Internal Audit Standards of Ukraine (UA Standards), the manager signs an internal audit declaration and approves provisions, programmes, regulatory documents, 
JAOC 19,6

Figure 2.

Main actors of public sector audit in Ukraine and their interrelations assurance and quality improvement programmes, as well as the IA workload, strategic and operational plans, etc. (MoF, 2011). Audit committees are formed in government agencies to discuss management, control and audit issues (MoF, 2019a).

\section{Research method and sources}

The evidential base is founded on qualitative analysis of primary and secondary data on public sector auditing in Ukraine. Data collection was conducted during February-April 2020 and July-August 2021. Primary data was collected through semi-structured interviews with public sector auditors; this type of interview is often referred to as a qualitative research interview (Saunders et al., 2015). Semi-structured interviews were chosen, as they contain both structured and unstructured sections with standardised and open-type questions (Walliman, 2011), thus providing an opportunity to dive into the auditors' "world" (Charmaz, 2014; Easterby-Smith et al., 2015).

In total, 29 interviews were conducted (for interviewees' background, see Appendix). To obtain a full picture of public sector auditing in Ukraine, both auditors at the ACU and IAs at the Ukrainian central government were interviewed. Self-selection and snowball sampling techniques were used in the search for respondents. Nineteen interviews were conducted during face-to-face meetings and recorded after receiving interviewees' consent. The remaining interviews took place remotely during phone discussions.

We applied a bricolage of several data sources (Wibberley, 2017); therefore, the data collection and analysis were organised as a three-stage process (Vakulenko et al., 2020). The first stage involved interviews with the ACU auditors, giving us a general understanding of public sector auditing in Ukraine. In the second stage, Ukrainian central government IAs provided information regarding their roles.

To complement the interviews, an analysis of secondary data was conducted during both stages. This included the following sources: official government documents, laws, statistics, central government regulatory documents and so on. The secondary data was analysed before and after the interviews (Saunders et al., 2015), to compare the evidence provided by respondents with relevant documents. During interviews, additional references to the secondary data and copies of internal documents were provided by the interviewees, reinforcing the empirical findings.

In the final stage, the data from interviews was translated into English from Ukrainian, allocated in a coherent way with the interview questions' topics and analysed based on the

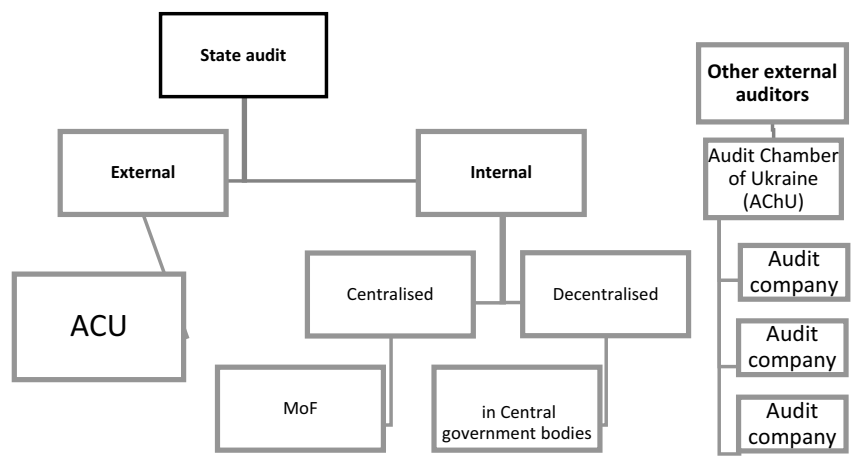

Source: Based on materials provided by External auditor 1 
themes presented above. The interviews were also repeated at this stage, to clarify the correct understanding of the meaning of terms. Due to a feasible number of interviews, the collected data was manually accessed. To simplify the analytical process and ensure that no information was lost, one of the analytical aids (i.e. the interview matrix on the Excel file) was applied (Saldana, 2014).

The research process was carried out with regard for ethical considerations. Transparency was assured by sending the interviewees information about the research project. As briefly mentioned above, consent to conduct the interviews was obtained. The option of anonymity was offered twice to each interviewee, before and after interviews. To ensure anonymity, code names were used for each interviewee; however, information required to understand the analysis is disclosed. Before interviews, permission for audiorecording was requested. During interviews, each respondent could stop answering at any point if feeling unsure or uncomfortable. Furthermore, interviewees were able to comment on the transcribed interviews.

To ensure reliability, primary data was collected from interviews with IAs in the Ukrainian central government, interviews were further repeated with some of the respondents. Secondary data was analysed with the same caution as the primary data. The use of more than one data analysis method enabled data triangulation, thus increasing the results' credibility (Patton, 2002).

\section{Findings}

\subsection{Heterogeneous role senders and their expectations}

To answer RQ1, we have identified the main role senders (Kahn et al., 1964; Katz and Kahn, 1978 ) in the Ukrainian central government. We divide them into two main groups by means of their contradicting expectations of IAs' roles:

(1) politicians, international organisations, MoF; and

(2) managers (i.e. heads of institutions).

Politicians in Ukraine (i.e. the legislative branch represented by Parliament and the Cabinet of Ministers of Ukraine) pass their expectations in the form of laws and regulations. As presented in the research context section above, with pressure from international organisations, the new Budget Code of Ukraine (Verkhovna Rada of Ukraine, 2010) has become the legal basis for introducing IAF into the Ukrainian central government, by separating it from the internal control system. The Cabinet of Ministers of Ukraine further adopted the key IAs' legal documents: Order No. 1001 and the National Internal Audit Standards of Ukraine (UA Standards):

In 2012, IA changed direction from revision to the audit. (IA10)

Before, it was not even called audit, it was control; we were making checks and revisions. (IA12)

Ukrainian politicians, therefore, place their expectation regarding IAs' role in Article 26 of the Budget Code of Ukraine:

[... the IAF aims for improvement in governance, internal control, preventing the facts of illegal, ineffective and inefficient use of budget funds, the occurrence of errors or other shortcomings in the activities of the manager of budget funds and enterprises, institutions and organizations related to his management, and provides independent conclusions and recommendations (Verkhovna Rada of Ukraine, 2010).

Changing roles of internal auditors 
JAOC 19,6

The same provisions are assigned to IAs in the UA Standards "Internal audit [...] contributes to the improvement of governance, internal control and risk management by adding independent and objective conclusions and recommendations" (UA Standard No. 5).

However, we find that the change in role was not visible until 2017, when the MoF's socalled "Harmonisation Department" was assigned to report twice yearly to the Cabinet of Ministers of Ukraine on the state of IAF in Ukraine's central government (Order No. 627):

\section{IAF as such started to develop from 2017 when the MoF took over all the IAF. (IA11)}

The MoF is responsible for the development of a model for reforming the system of audit activity in Ukraine in accordance with international standards and best practices. In cooperation with the Ministry of Finance of The Netherlands, the MoF developed new methodological guidelines for internal auditing in the Ukrainian public sector in 2019 (IA Guidelines). According to IA Guidelines, IAs are presented as "helpers" and "supporters" of managers and institutions, due to their independent and objective assessment. According to IA Guidelines, IAs are expected to provide recommendations on:

- improving the governance system and internal control, including risk management processes;

- improving policies and procedures to prevent illegal, inefficient and ineffective use of budget funds, the occurrence of errors or other shortcomings in the institution's activities; and

- strengthening accountability and improving the effectiveness of the institution, etc. (MoF, 2019a).

The MoF set expectations regarding implementation of recommendations by the IA Guidelines in three main areas: governance, internal control and risk management. Moreover, IA Guidelines state that the IA's role should not be limited to inspection activities aimed at identifying evidence of violations and providing written requirements to eliminate such (MoF, 2019a).

Therefore, we find that, in institutional and regulatory ways, Ukraine meets International Standards for the Professional Practice of Internal Auditing (IIA Standards) and claims a change in IAs' role in Ukraine's central government. However, from our interviews, it became clear that there is no real compliance between the legislature provisions and real IAF practices:

The way IAs' role is now formed in the Budget Code is not present in practice. (IA2)

Unfortunately, I do not see the radical change that was expected with the introduction of the new legal basis; IAs remain "watchdogs". (R6)

Here, we turn to the second group of role senders: managers (i.e. heads of institutions). According to the Budget Code of Ukraine, "to carry out IAF, the manager of budgetary funds forms an independent structural unit of IAs, which is subordinated and accountable directly to the manager" (Verkhovna Rada of Ukraine, 2010). According to the new legislation, managers sign an internal audit declaration, indicating the purpose (mission) and goals, as well as the independence and responsibilities, of the internal audit department. Managers' expectations are formed in the internal documents of the organisation (e.g. internal audit provisions, programmes, strategic and operational plans, etc.). 
We find that institutional and regulatory change did not lead to real change in IAs' role as expected by politicians and international organisations, firstly because managers only introduced IAF in Ukraine's central government to comply with the new legislation:

They took me to fill the vacant position, as they are now obliged to have at least one IA. (IA13)

The manager doesn't need this "new" function if it becomes more and more invisible [respondent means the tendency to reduce the number of IAs the institution employs]. (IA12)

Secondly, we find that, due to Ukraine's unstable political situation and the number of ongoing reforms, managers in Ukraine frequently change ["at some institutions, managers can change three to four times a year!" (MoF specialist)], and there is general unawareness about the role of IAs ["managers do not fully understand the role, abilities and importance of IAF” (MoF specialist)]:

They [managers] expect us to check the objects in which they are most interested. (IA16)

Due to the lack of understanding of IAs' role, the Methodological Guidelines for Internal Performance Audit (IPA Guidelines) state that "IAF is still often perceived by management as an inspection/control function aimed at detecting irregularities related to financial processes" (MoF, 2019b, p. 3):

As they perceive auditors as revisors, they expect us to search for mistakes and violations. (IA3)

Consequently, we find that heterogeneous role senders (politicians, international organisations, the MoF and managers) place IAs in multi-expectation situations, causing them to experience inter-sender conflict (Kahn et al., 1964), which impedes change in their role in Ukraine's central government. It is difficult for IAs to develop in the direction of preventing shortcomings and improving the institution's activities (MoF, 2018, 26 June). Moreover, the risk-oriented approach is mostly formal and lacks a systematic risk analysis that should be performed by both management and the internal audit department (MoF, 2018, 26 June). IAs in the Ukrainian public sector have yet to reach the level of serving as internal guarantors and advisors for management (MoF, 2018, 26 June):

The current state of internal auditing is not as effective as it should be. (IA1)

Most informants perceive their roles de facto as those of revisors or inspectors who must search for and eliminate violations. Those findings complement the IAF review, which shows that IAs have not shaken off their inspection roots, in both perception (particularly by management) and approaches to work.

\subsection{Internal auditors' response to role conflict}

We find that IAs in Ukraine choose behavioural coping efforts (Merton, 1949) to face the clash in expectations due to inter-sender role conflict (Kahn et al., 1964). However, their response depends on factors at three different levels: experience and knowledge as a personal factor at the micro-level, independence as a relationship-related factor at the meso-level and working environment as an organisational factor at the macro-level.

6.2.1 Experience and knowledge. The ability to see the existing role conflict and accept the specific role much depends on the experience and knowledge that IAs possess:

The problem is twofold - how managers understand IAs' role and how IAs understand their role. (SAS auditor 2) 
JAOC 19,6

Considering the specifics of the research context, IAs' experience has a direct impact on their perception of their role and their response to role conflict. Because of the history of the existence of the "Control-Revision Department," most IAs have previously worked as revisors or financial inspectors. Consequently, they prioritise managers' expectations and continue performing the same functions, as "they feel comfortable remaining watchdogs" (SAS auditor):

IAF is new for Ukraine, and we do not have people with experience in audits, not revisions. Most auditors have a revisor past - they are used to conducting checks of objects [. . . ] it is better to take someone without a revisor past and teach from zero. But here we face another problem: new IAs are constantly coming who do not understand their role. (MoF specialist)

The IAF review presents a high staff turnover rate (up to $50 \%$ in small units); a lack of appropriate skills, competencies and knowledge; and insufficient training and resources for internal audit units (MoF, 2018, 26 June). IAs state that, to perform their new role, they need constant training and experience exchange, as it is impossible for someone with a revision and accounting background to start conducting performance audits:

There is a lack of qualified specialists who can effectively find weaknesses in the activity of the institution and provide high quality recommendations to ensure its optimal operation. (IA6)

We also find that, while making claims about the change in their role, some respondents were unaware of the specifics of their new role. IA5 connected IAs' role with the ability to ensure financial discipline at the institution, while IA14 claimed that IAs perform financial control. Both claims can be used to explain the traditional "watchdog" role, rather than the new role, therefore raising concerns about IAs' knowledge. The MoF places strong emphasis on learning activities for IAs, moreover, "working on national certification to improve the skills of IAs and planning to increase salaries by $30 \%$ to attract more qualified employees" (MoF specialist).

6.2.2 Independence. We find that IAs are facing challenges in fulfilling their new role, despite their wishes, because management requires other actions, namely, identifying violations:

While auditors try to give recommendations, managers expect them to limit their functions to identifying errors and violations. [...] Our managers do not consider IAs as consultants or assistants; they simply do not even understand how someone can give them advice and "manage" them. Therefore, they continue to consider them as - and force them to perform the role of "watchdogs." (External auditor 1 about IAs)

The MoF (2018, 26 June) identified that the principles of the organisational and functional independence of internal audit units, defined by national legislation, are not always present in practice. We see that the existing system does not ensure the independence of IAs:

I think that IAs cannot be independent as they are now [...] IAs appeared to be tools for the manager's influence over the processes at the institution. (SAS auditor 2)

The idea of subordinating IAs directly to the manager is to make them free of any influence. (MoF specialist)

However, we see the situation in which managers appear to have the power to influence IAs' work, considering this strong direct link between managers and IAs. Consequently, we find that IAs who lack independence choose to prioritise managers' expectations, as they are fully dependent on the manager's will and understanding of their role: 
IAs' role depends on how the manager generally perceives IAs; some see them as helpers and some as an "evil force that comes from Europe." (IA15)

We also find that, in rare cases where IAs are not influenced by the manager, it is possible for them to successfully modify managers' demands:

I have looked through the audit reports issued before I came, and I understood that there were only the audits of the subordinated object (only financial and compliance audits), but the activities of the institution itself were not analysed. I have changed this practice, with the manager's support. (IA10)

However, the system and legislation should guarantee IAs' independence, so that managers' will does not play a central part in framing IAs' role.

6.2.3 Working environment. The legal and regulatory environment reflects the general expectations of a role set in a given context, therefore shaping the role behaviour (Katz and Kahn, 1978; Roussy, 2013). We find that the legal and regulatory bases of IAF do not seem to account for many issues that IAs face.

According to the IAF review, IAF is never fully carried out, due to complete understaffing ( $40 \%$ of internal audit units had only one or two IAs). For example, one IA at the Ministry of Education and Science of Ukraine had 242 objects to audit in 2018. COVID-19 also had an impact, as now all departments lack employees (IA11). However, no legal documents were issued to increase the number of IAs:

We lack normative provisions to increase the number of IAs. (IA8)

The number of people employed as IAs is decided by the manager and depends on the funding (and we never have enough funding). (IA11)

Consequently, some IAs may prioritise managers' expectations because of the physical inability to perform their new role:

There should be at least a department to properly perform the new role, but I am the only IA in the whole ministry. (IA12)

Moreover, we find that, because of weak internal control mechanisms or even their absence in some institutions, IAs can be forced to perform traditional control and inspection functions instead:

No one performs the function of control [. . . ] as a result, it is placed on us. (IA1)

They were separated, but internal audit function is really the same as control. (IA2)

[... the weak link is the internal control system. (External auditor 1 about IAs)

\section{Discussion and conclusions}

Through role theory lenses (Kahn et al., 1964; Katz and Kahn, 1978), we developed a theoretical model of the process of IAs' role enactment (Figure 3). It enriches the understanding of auditors' roles; role conflict, which auditors may experience (Kahn et al., 1964); role senders and their expectations; and how conflicting expectations place auditors into multi-expectation situations (Davidson, 1975). Moreover, we identified the personal, relationship-related and organisational factors which affect how IAs cope with role conflict (Lynch, 2007; Wickham and Parker, 2007; Katz and Kahn, 1978). The theoretical model can 


\section{$\mathrm{JAOC}$ 19,6}

\section{4}

Figure 3.

Process of IAs' role enactment

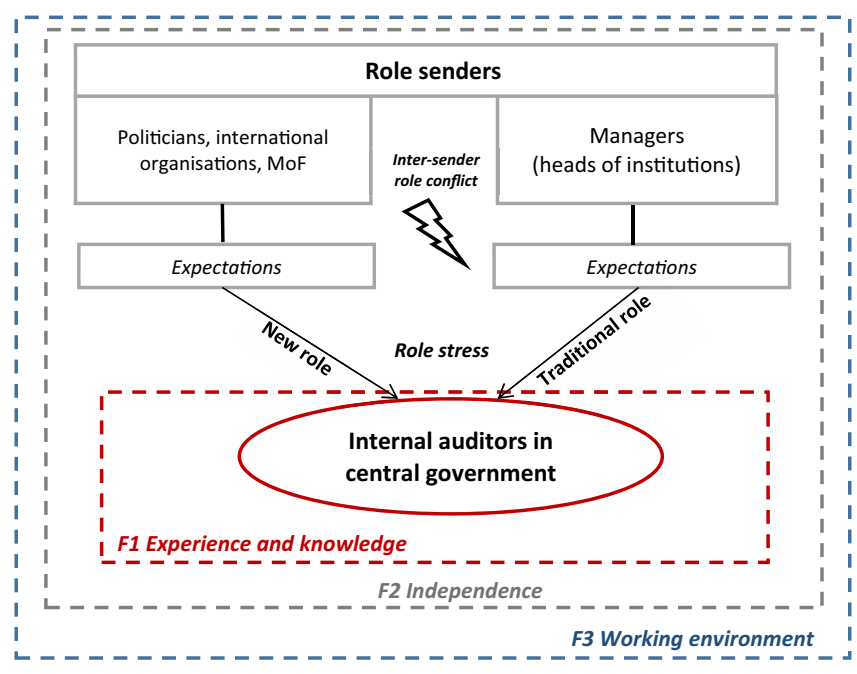

be widely used in future studies on public sector auditing in different countries facing similar challenges.

This study contributes both empirically and theoretically to the performance audit literature, with an unexplored case of a post-Soviet country - Ukraine. We find that the roles IAs perform are not in perfect compliance with the current legal and regulatory framework supporting the study by Roussy (2013). We go further, arguing that such inconsistency appears because of the multi-expectation situation (Davidson, 1975) in which IAs find themselves, due to the division of the heterogeneous role senders into two different areas.

Change in IAs' roles in the Ukrainian central government created two groups of role senders, divided by their contradicting expectations of IAs' roles (see Figure 3). The expectations of the first group of role senders - politicians, international organisations and the $\mathrm{MoF}$ - converge and were found to be generally represented in the legal and regulatory framework (i.e. Budget Code of Ukraine, IIA Standards, UA Standards, IA Guidelines, IPA Guidelines). IAs are expected to improve governance and internal control; prevent illegal, ineffective and inefficient use of budget funds, as well as the occurrence of errors or other shortcomings in the activities of the manager and the enterprises, institutions and organisations related to his management; and provide independent conclusions and recommendations (Verkhovna Rada of Ukraine, 2010). Their expectations reflect the new approach regarding the role of IAs in the literature, arising with the introduction of performance auditing (Roussy, 2013; Morin and Hazgui, 2016; Deloitte, 2018). However, we find that politicians in Ukraine enacted new regulations to please international actors (i.e. IMF, WB and EBRD), but not to lay foundation for performance audit in Ukraine.

Consequently, we further evidence the absence of change in the expectations of the second group of role senders - public managers (heads of institutions), who still perceive IAs as traditional "watchdogs." Managers introduce IAF to comply with new legislation; they face general problems understanding IAs' role and identify them as revisors, as IAs were before, expecting inspection and control activities, thus putting IAs in multi-expectation situations (Davidson, 1975).

In contrast with the study by Van Peursem (2004), who found that most IAs did not recognise their dual role as a problem, we find that IAs in the Ukrainian central government 
suffer role stress (Kahn et al., 1964). Positioned between two groups of role senders with contradictory expectations, IAs experience inter-sender conflict (Kahn et al., 1964), which impedes the change in their role. With those findings, we add to the prior research on role conflicts in internal auditing (Van Peursem, 2005; Ahmad and Taylor, 2009; Roussy, 2013; Roussy, 2015).

Faced with mutually exclusive expectations, IAs cannot make proper judgements about which one to satisfy (Koo and Sim, 1999). Moreover, the study identified the number of personal, organisational and relationship-related factors (Katz and Kahn, 1978) on three different levels which influence the way IAs cope with role conflict and choose to prioritise the traditional "watchdog" (control, inspection) of managers' expectations (see Figure 3).

The first factor with a direct impact on IAs' perception of their role and their response to role conflict is their experience. As most IAs have previously worked as revisors or financial inspectors, they may choose to follow managers' expectations, as those are similar to the skills they possess. Moreover, the lack of IAs' knowledge also has a direct impact and creates problems with the enactment of their new role. Documents issued in recent years (e.g. IA, IPA Guidelines) consist of well-defined and clarified expectations, as well as detailed guides for the role of IAs. However, we still find that role ambiguity (Kahn et al., 1964) is present among IAs and managers regarding the new role of IAs. Role ambiguity may decrease with the training of IAs, as proposed by Aghghaleh et al. (2014); however, we also find that employees with different backgrounds and better resource allocation for internal audit units are needed.

The Ukrainian case also indicated independence as a relationship-related factor that affects IAs' response to role conflict. As argued by Ahmad and Taylor (2009), the more internal role conflicts auditors experience, the less importance they place on independence. Several studies are concerned with how to ensure the independence of IAs with the change in their role, as they are now becoming managers' advisors (Betti and Sarens, 2021; Ahmad and Taylor, 2009). We support those studies with the evidence from Ukraine's central government and show that the new legislative framework, aimed at changing IAs' role, failed to ensure their independence. Consequently, by appearing fully dependent on managers, IAs choose to prioritise their expectations and perform a traditional "watchdog" role instead. A separate study is required on the issue within the same context, to obtain a clear picture of the level of independence of IAs in the Ukrainian central government.

We also find that the existing organisational environment within the Ukrainian central government (weak internal control mechanisms or even their absence) impedes IAs from improving the internal systems, as they are forced to perform traditional control and inspection functions. The next organisational factor is the enormous workload due to the critical understaffing within the organisations IAs work for. Few IAs are not able to perform an in-depth assessment of the economy, efficiency and effectiveness of huge governmental institutions as expected with the introduction of performance auditing. By identifying those organisational factors, our findings contribute to the study by Ahmad and Taylor (2009) and suggest that changes are needed not only in IAs' roles but also in the working environment surrounding IAs in the organisation.

The degree of stress experienced by IAs because of role conflict might be reduced if managers were more aware of the characteristics of the organisational climate related to conflict. In other words, various forms of managerial support are needed in the fulfilment of a specific role (Taminiau and Heusinkveld, 2017). The creation of a strong internal control system would place the control role on the right actors at the institution, giving IAs the ability to perform their new roles in the three areas of governance, internal control and risk 
management. With the support from politicians, the assurance of IAs' independence, the resources for attracting more qualified employees and development of educational and training programmes would ensure IAs' new roles are performed properly. IAs in the Ukrainian central government attempt to modify demands in response to stress (Merton, 1949; Kahn et al., 1964). However, we find that their experience and knowledge, independence and the specifics of the working environment make them prioritise manager's expectations. Consequently, we claim that more attention should be paid to mitigate the impact of the analysed factors to ensure IAs' ability to enact and communicate their new role to managers.

Future studies might continue to improve knowledge on performance auditing and IAs' role, by focusing on role senders, expectations and the role conflicts that IAs may experience, through the use of the proposed theoretical model of the process of IAs' role enactment (Figure 3). Comparative analyses of IAs' roles in other post-Soviet countries and other emerging countries may enrich the debate with interesting findings on performance auditing and its impact in the public sector (Nerantzidis et al., 2020; Mattei et al., 2021), as well as widening role theory. The relations between IAs and other governance mechanisms, particularly the audit committee, the board of directors, top management team and external auditors (Roussy, 2013), should also be studied. Moreover, the issue of IAs' independence in the public sector and their role in fighting and preventing fraud and corruption requires further research (Gustavson and Sundström, 2018; Cesário et al., 2020). Additionally, little research exists on the role of international organizations (such as the International Organisation of Supreme Audit Institutions' Development Initiative) in emerging countries in enhancing the capacity and performance on public sector auditors (Gørrissen, 2020).

\section{References}

ACCA. (2014), "Breaking out: public audit's new role in a post-crash world", Association of Chartered Certified Accountants, available at: www.accaglobal.com (accessed 21 April 2020).

Aghghaleh, F., Mohamed, M. and Ahmad, A. (2014), "The effects of personal and organizational factors on role ambiguity amongst internal auditors", International Journal of Auditing, Vol. 18 No. 2 , pp. 105-114.

Ahmad, Z. and Taylor, D. (2009), "Commitment to independence by internal auditors: the effects of role ambiguity and role conflict", Managerial Auditing Journal, Vol. 24 No. 9, pp. 899-925.

Archambeault, D., DeZoort, F. and Holt, T. (2008), "The need for an internal auditor report to external stakeholders to improve governance transparency", Accounting Horizons, Vol. 22 No. 4, pp. 375-389.

Asare, T. (2008), "Internal auditing in the public sector: promoting good governance and performance improvement", International Journal of Government Financial Management, Vol. 9 No. 1, pp. 12-27.

Barasa, K.S. (2015), "Statistical analysis of the role of internal audit in promoting good governance in public institutions in Kenya”, Journal of Investment and Management, Vol. 4 No. 1, pp. 38-46.

Barzelay, M. (1997), "Central audit institutions and performance auditing: a comparative analysis of organizational strategies in the OECD”, Governance, Vol. 10 No. 3, pp. 235-260.

Betti, N. and Sarens, G. (2021), "Understanding the internal audit function in a digitalised business environment", Journal of Accounting and Organizational Change, Vol. 17 No. 2, pp. 197-216.

Biddle, B. (1986), "Recent development in role theory", Annual Review of Sociology, Vol. 12 No. 1, pp. 67-92.

Bouckaert, G., Nakrošis, V. and Nemec, J. (2011), "Public administration and management reforms in CEE: main trajectories and results", Journal of Public Administration and Policy, Vol. 4, pp. 9-29. 
Bunn, M., Pilcher, R. and Gilchrist, D. (2018), "Public sector audit history in Britain and Australia", Financial Accountability and Management, Vol. 34 No. 1, pp. 64-76.

Burkert, M., Fischer, F.M. and Schäffer, U. (2011), "Application of the controllability principle and managerial performance: the role of role perceptions", Management Accounting Research, Vol. 22 No. 3, pp. 143-159.

Centre for Adaptation of the Civil Service. (2019), "Cooperation with the SIGMA programme in 2018", 16 January, available at: www.center.gov.ua/en/press-center/articles/item/3282-cooperationwith-the-sigma-programme-in-2018 (accessed 11 May 2020).

Cesário, G., Cardoso, R.L. and Aranha, R.S. (2020), "The surveillance of a supreme audit institution on related party transactions", Journal of Public Budgeting, Accounting and Financial Management, Vol. 32 No. 4, pp. 577-603.

Charmaz, K. (2014), Constructing Grounded Theory: A Practical Guide through Qualitative Analysis, 2nd ed., Sage Publications, London.

Christopher, J. (2019), "The failure of internal audit: monitoring gaps and a case for a new focus", Journal of Management Inquiry, Vol. 28 No. 4, pp. 472-483.

Dan, S. and Pollitt, C. (2015), "NPM can work: an optimistic review of the impact of new public management reforms in central and Eastern Europe”, Public Management Review, Vol. 17 No. 9, pp. 1305-1332.

Davidson, L. (1975), "The role and responsibilities of the auditor: perspective, expectations and analysis", Unpublished Background Paper for the Commission on Auditors' Responsibilities.

De Koning, R. (1999), "PIfC in the context of European union enlargement", SIGMA Public Management Forum, Paris, France, Vol. 6, available at: www.academia.edu/2029867/ PIFC_in_the_context_of_European_Union_Enlargement (accessed 14 April 2020).

Deloitte. (2018), "The innovation imperative: forging internal audit's path to greater impact and influence", Deloitte's 2018 Global Chief Audit Executive Research Survey, available at: www2.deloitte.com/ global/en/pages/risk/articles/global-chief-audit-executive-survey-reporthtml (accessed 21 April 2020).

Easterby-Smith, M., Thorpe, R. and Jackson, P. (2015), Management Research, 5th ed., Sage Publications, London.

Ebimobowei, A. and Kereotu, O.J. (2011), "Role theory and the concept of audit expectation gap in South-South, Nigeria”, Research Journal of Social Sciences, Vol. 3 No. 6, pp. 445-452.

Ferry, L. and Ahrens, T. (2021), "The future of the regulatory space in local government audit: a comparative study of the four countries of the United Kingdom", Financial Accountability and Management, Vol. ahead-of-print No. ahead-of-print, available at: https://doi.org/10.1111/faam.12291

Ferry, L. and Midgley, H. (2021), "Democracy, accountability and audit: the creation of the UK NAO as a defence of liberty", Accounting, Auditing and Accountability Journal, Vol. 35 No. 2, pp. 413-438.

Ferry, L., Zakaria, Z., Zakaria, Z. and Slack, R. (2017), "Watchdogs, helpers or protectors? -internal auditing in Malaysian local government”, Accounting Forum, Vol. 41 No. 4, pp. 375-389.

Fischer, F. (2010), The Application of the Controllability Principle and Managers' Responses: A Role Theory Perspective, Springer Science and Business Media, Gabler, Wiesbaden.

Fondas, N. and Stewart, R. (1994), "Enactment in managerial jobs: a role analysis", Journal of Management Studies, Vol. 31 No. 1, pp. 83-103.

Gendron, Y., Cooper, D. and Townley, B. (2001), "In the name of accountability - state auditing, independence and new public management", Accounting, Auditing and Accountability Journal, Vol. 14 No. 3, pp. 278-310.

Gendron, Y., Cooper, D. and Townley, B. (2007), "The construction of auditing expertise in measuring government performance", Accounting, Organizations and Society, Vol. 32 Nos 1/2, pp. 101-129. 
Gørrissen, E. (2020), "The role of the INTOSAI development initiative (IDI) in strengthening the capacity and performance of supreme audit institutions in developing countries", Journal of Public Budgeting, Accounting and Financial Management, Vol. 32 No. 4, pp. 729-733.

Gustavson, M. and Sundström, A. (2018), "Organising the audit society: does good auditing generate less public sector corruption?”, Administration and Society, Vol. 50 No. 10, pp. 1508-1532.

Hay, D. and Cordery, C. (2018), "The value of public sector audit: literature and history", Journal of Accounting Literature, Vol. 40, pp. 1-15.

Hay, D.C. and Cordery, C.J. (2021), "The future of auditing research in the public sector", Journal of Public Budgeting, Accounting and Financial Management, Vol. 33 No. 2, pp. 234-242.

Hood, C. (1995), "Contemporary public management: a new global paradigm?", Public Policy and Administration, Vol. 10 No. 2, pp. 104-117.

Kahn, R.L., Wolfe, D.M., Quinn, R.P., Snoek, J.O. and Rosenthal, R.A. (1964), Organizational Stress: Studies in Role Conflict and Ambiguity, John Wiley and Sons, New York, NY.

Katz, D. and Kahn, R.L. (1978), The Social Psychology of Organizations, John Wiley and Sons, New York, NY.

Koo, C.M. and Sim, H.S. (1999), "On the role conflict of auditors in Korea", Accounting, Auditing and Accountability Journal, Vol. 12 No. 2, pp. 206-219.

Kotb, A., Elbardan, H. and Halabi, H. (2020), "Mapping of internal audit research: a post-Enron structured literature review", Accounting, Auditing and Accountability Journal, Vol. 33 No. 8, pp. 1969-1996.

Kraan, D., Trapp, L., Kostyleva, V., Tuinen, J. and Morgner, M. (2013), "Budgeting in Ukraine”, OECD Journal on Budgeting, Vol. 12 No. 2, pp. 69-140.

Kurunmaki, L. (1999), "Professional vs financial capital in the field of health care - struggles for the redistribution of power and control", Accounting, Organizations and Society, Vol. 24 No. 2, pp. 95-124.

Lapsley, I. and Miller, P. (2019), “Transforming the public sector: 1998-2018”, Accounting, Auditing and Accountability Journal, Vol. 32 No. 8, pp. 2211-2252.

Liu, A.H., Gould, A.N., Rollins, M. and Gao, H. (2014), "Role conflict and ambiguity confronting transnational business networkers: contrasting social stigma and relational risks for Chinese and Western boundary spanners", Industrial Marketing Management, Vol. 43 No. 6, pp. 911-919.

Lynch, K.D. (2007), "Modeling role enactment: linking role theory and social cognition", Journal for the Theory of Social Behaviour, Vol. 37 No. 4, pp. 379-399.

Mattei, G., Grossi, G. and Guthrie, J. (2021), "Exploring past, present, and future trends in public sector auditing research: a literature review", Meditari Accountancy Research, Vol. 29 No. 7, pp. 94-134, doi: 10.1108/MEDAR-09-2020-1008.

Merton, R. (1949), Social Theory and Social Structure: Toward the Codification of Theory and Research, Free Press, Glencoe, IL.

Michael, A. (2001), Human Resources Management Practice, Kogan Page, London.

Miedviedkova, N. (2016), "Directions for improvement of state financial control in Ukraine", Baltic Journal of Economic Studies, Vol. 2 No. 2, pp. 105-110.

MoF. (2011), "Internal audit standards", Order of the Ministry of Finance of Ukraine No. 1247, 4 October, available at: http://zakon3.rada.gov.ua/laws/show/z1219-11 (accessed 23 April 2020).

MoF. (2018), "Information on the results of the review of internal audit function, discussed with internal auditors”, Ministry of Finance of Ukraine, 26 June, available at: https:// mof.gov.ua/uk/news/rezultaty-ohliadu-funktsii-vnutrishnoho-audytu-v-derzhavnykhorhanakh-obhovoreni-z-vnutrishnimy-audy toramy (accessed 23 April 2020).

MoF. (2019a), "Methodological guidelines for internal audit in the public sector of Ukraine", ministry of finance of Ukraine, available at: https://mof.gov.ua/uk/rozvitok-derzhavnogo-vnutrishnogofinansovogo-kontrolju (accessed 21 April 2020). 
MoF. (2019b), "Methodological guidelines for internal performance audit in the public sector of Ukraine", Ministry of Finance of Ukraine, available at: https://mof.gov.ua/uk/rozvitokderzhavnogo-vnutrishnogo-finansovogo-kontrolju (accessed 22 April 2020).

MoF. (2019c), "The ministries of finance of Ukraine and The Netherlands signed a memorandum on technical cooperation", Ministry of Finance of Ukraine, 18 October, available at: https://mof.gov. ua/uk/news/ministerstva_finansiv_ukraini_ta_niderlandiv_pidpisali_memorandum_pro_vzaie morozuminnia_shchodo_tekhnichnogo_spivrobitnitstva-1854 (accessed 10 May 2020).

Morin, D. (2001), "Influence of value for money audit on public administrations: looking beyond appearances", Financial Accountability and Management, Vol. 17 No. 2, pp. 99-117.

Morin, D. (2003), "Controllers or catalysts for change and improvement: would the real value for money auditors please stand up?", Managerial Auditing Journal, Vol. 18 No. 1, pp. 19-30.

Morin, D. and Hazgui, M. (2016), "We are much more than watchdogs: the dual identity of auditors at the UK national audit office", Journal of Accounting and Organizational Change, Vol. 12 No. 4, pp. 568-589.

Nerantzidis, M., Pazarskis, M., Drogalas, G. and Galanis, S. (2020), "Internal auditing in the public sector: a systematic literature review and future research agenda", Journal of Public Budgeting, Accounting and Financial Management, Vol. ahead-of-print No. ahead-of-print, available at: https://doi.org/10.1108/JPBAFM-02-2020-0015

Parker, L.D., Jacobs, K. and Schmitz, J. (2018), "New public management and the rise of public sector performance audit: evidence from the Australian case", Accounting, Auditing and Accountability Journal, Vol. 32 No. 1, pp. 280-306.

Parker, L.D., Schmitz, J. and Jacobs, K. (2021), "Auditor and auditee engagement with public sector performance audit: an institutional logics perspective", Financial Accountability and Management, Vol. 37 No. 2, pp. 142-162.

Patton, M.Q. (2002), "Two decades of developments in qualitative inquiry: a personal, experiential perspective", Qualitative Social Work, Vol. 1 No. 3, pp. 261-283.

Pearson, D. (2014), "Significant reforms in public sector audit - staying relevant in times of change and challenge", Journal of Accounting and Organizational Change, Vol. 10 No. 1, pp. 150-161.

Pierre, J. and de Fine Licht, J. (2019), "How do supreme audit institutions manage their autonomy and impact? A comparative analysis", Journal of European Public Policy, Vol. 26 No. 2, pp. 226-245.

Pierre, J., Peters, G. and Licht, J. (2018), "Is auditing the new evaluation? Can it be? Should it be?", International Journal of Public Sector Management, Vol. 31 No. 6, pp. 726-739.

Pollitt, C. (2003), "Performance audit in Western Europe: trends and choices", Critical Perspectives on Accounting, Vol. 14 Nos 1/2, pp. 157-170.

Pollitt, C. and Summa, H. (1996), "Performance audit and evaluation: similar tools, different relationships?”, New Directions for Evaluation, Vol. 1996 No. 71, pp. 29-50.

Power, M. (1994), The Audit Explosion, Demos, London.

Power, M. (1999), The Audit Society: Rituals of Verification, Oxford University Press, Oxford.

Power, M. (2005), "The theory of the audit explosion", in Ferlie, E., Lynn, L.E. and Pollitt, C. (Eds), The Oxford Handbook of Public Management, Oxford University Press, Oxford, pp. 326-346.

Reichborn-Kjennerud, K. and Johnsen, A. (2018), "Performance audits and supreme audit institutions' impact on public administration: the case of the office of the auditor general in Norway", Administration and Society, Vol. 50 No. 10, pp. 1422-1446.

Rizzo, J.R., House, R.J. and Lirtzman, S.I. (1970), "Role conflict and ambiguity in complex organizations", Administrative Science Quarterly, Vol. 15 No. 2, pp. 150-163.

Rodham, K. (2000), "Role theory and the analysis of managerial work: the case of occupational health professionals", Journal of Applied Management Studies, Vol. 9 No. 1, pp. 71-81. 
Romzek, B. (2000), "Dynamics of public sector accountability in an era of reform”, International Review of Administrative Sciences, Vol. 66 No. 1, pp. 21-44.

Roussy, M. (2013), "Internal auditors' roles: from watchdogs to helpers and protectors of the top manager", Critical Perspectives on Accounting, Vol. 24 Nos 7/8, pp. 550-571.

Roussy, M. (2015), "Welcome to the day-to-day of internal auditors: how do they cope with conflicts?", AUDITING: A Journal of Practice and Theory, Vol. 34 No. 2, pp. 237-264.

Roussy, M. and Perron, A. (2018), "New perspectives in internal audit research: a structured literature review", Accounting Perspectives, Vol. 17 No. 3, pp. 345-385.

Saldana, J. (2014), Thinking Qualitatively: Methods of Mind, SAGE Publications, Thousand Oaks.

Saunders, M., Lewis, P. and Thornhill, A. (2015), Research Methods for Business Students, Pearson Education, New York.

Schillemans, T., van Twist, M., van der Steen, M. and de Jong, I. (2018), "New development: breaking out or hanging on? Internal audit in government", Public Money and Management, Vol. 38 No. 7 , pp. 531-534.

Taminiau, Y. and Heusinkveld, S. (2017), "Role expectations and agency in the audit tendering process", Accounting, Auditing and Accountability Journal, Vol. 30 No. 8, pp. 1820-1842.

Tillema, S. and ter Bogt, H.J. (2010), "Performance auditing. Improving the quality of political and democratic processes?", Critical Perspectives on Accounting, Vol. 21 No. 8, pp. 754-769.

Vakulenko, V., Bourmistrov, A. and Grossi, G. (2020), "Reverse decoupling: Ukrainian case of healthcare financing system reform", International Journal of Public Sector Management, Vol. 33 No. 5, pp. 519-534.

Van Peursem, K. (2004), "Internal auditors' role and authority: New Zealand evidence", Managerial Auditing Journal, Vol. 19 No. 3, pp. 378-393.

Van Peursem, K. (2005), "Conversations with internal auditors: the power of ambiguity”, Managerial Auditing Journal, Vol. 20 No. 5, pp. 489-512.

Verkhovna Rada of Ukraine. (2010), "Budget code of Ukraine”, Code of Ukraine No. 2543-III, 21 June, available at: http://zakon1.rada.gov.ua (accessed 10 April 2020).

Walliman, N. (2011), The Basics, Routledge, London.

Wibberley, C. (2017), "Bricolage research methods", in Glasper, E.A. and Rees, C. (Eds), Health Care Research: At a Glance, Wiley-Blackwell, Oxford, pp. 6-107.

Wickham, M. and Parker, M. (2007), "Reconceptualising organizational role theory for contemporary organizational contexts", Journal of Managerial Psychology, Vol. 22 No. 5, pp. 440-464.

Wildavsky, A. (1964), The Politics of the Budgetary Process, Brown and Co, Toronto: Little.

Yang, L. (2021), “Auditor or adviser? Auditor (in)dependence and its impact on financial management", Public Administration Review, Vol. 81 No. 3, pp. 475-487. 


\begin{tabular}{|c|c|c|c|c|c|}
\hline$\#$ & Interviewee code & Position & Institution & Form/duration & ilors \\
\hline \multicolumn{6}{|c|}{ February-April 2020} \\
\hline \multirow[t]{2}{*}{1.} & ACU auditor 1 & $\begin{array}{l}\text { Deputy Director of } \\
\text { the Department for } \\
\text { the Use of the State }\end{array}$ & The Accounting Chamber & Meeting/1 h & 21 \\
\hline & & Budget in the Regions & & & \\
\hline \multirow[t]{7}{*}{2.} & ACU auditor 2 & Head of the & & Meeting/40 min & \\
\hline & & Department for & & & \\
\hline & & $\begin{array}{l}\text { Adaptation and } \\
\text { Implementation of }\end{array}$ & & & \\
\hline & & International & & & \\
\hline & & Standards for & & & \\
\hline & & International & & & \\
\hline & & Cooperation & & & \\
\hline 3. & ACU auditor 3 & Anonymous & & Phone call/25 min & \\
\hline 4. & ACU auditor 4 & Anonymous & & Phone call/30 min & \\
\hline 5. & SAS auditor & $\begin{array}{l}\text { North Office, Head of } \\
\text { Department }\end{array}$ & $\begin{array}{l}\text { The State Audit Service of } \\
\text { Ukraine }\end{array}$ & Meeting/55 min & \\
\hline 6. & $\begin{array}{l}\text { External auditor } \\
1\end{array}$ & $\begin{array}{l}\text { Director of the Centre } \\
\text { for Advanced Studies } \\
\text { of National } \\
\text { University of Kyiv }\end{array}$ & External Auditor & Meeting/1.5 h & \\
\hline 7. & $\begin{array}{l}\text { External auditor } \\
2\end{array}$ & $\begin{array}{l}\text { Board member of the } \\
\text { Audit Chamber of } \\
\text { Ukraine }\end{array}$ & External Auditor & Phone call/25 min & \\
\hline 8. & $\begin{array}{l}\text { External auditor } \\
3\end{array}$ & $\begin{array}{l}\text { Chairman of the } \\
\text { Federation Council }\end{array}$ & $\begin{array}{l}\text { Federation of Auditors, } \\
\text { Accountants and Financiers } \\
\text { of AIC of Ukraine }\end{array}$ & Phone call/30 min & \\
\hline 9. & IA1 & $\begin{array}{l}\text { Head of Department } \\
\text { Internal Auditor }\end{array}$ & $\begin{array}{l}\text { Ministry of Culture, Youth } \\
\text { and Sports of Ukraine }\end{array}$ & Meeting $/ 50 \mathrm{~min}$ & \\
\hline 10. & IA2 & Internal Auditor & $\begin{array}{l}\text { State Service of Ukraine } \\
\text { on Drugs Control }\end{array}$ & Phone call/30 min & \\
\hline 11. & IA3 & $\begin{array}{l}\text { Head of Internal } \\
\text { Audit Department }\end{array}$ & $\begin{array}{l}\text { State Service of Ukraine on } \\
\text { Food Safety and Consumers' } \\
\text { Protection (SSFSCP) }\end{array}$ & Phone call/35 min & \\
\hline 12. & IA4 & Internal Auditor & Anonymous & Phone call/25 min & \\
\hline 13. & IA5 & $\begin{array}{l}\text { Chief Specialist of the } \\
\text { Internal Audit Sector }\end{array}$ & $\begin{array}{l}\text { Ministry of Development } \\
\text { of Communities and } \\
\text { Territories of Ukraine }\end{array}$ & Phone call/30 min & \\
\hline 14. & IA6 & $\begin{array}{l}\text { Chief Specialist of the } \\
\text { Audit Department of } \\
\text { the Budgeting } \\
\text { Institutions of the } \\
\text { Internal Control and } \\
\text { Audit Department }\end{array}$ & Kyiv City Council & Phone call/20 min & \\
\hline \multirow[t]{3}{*}{15.} & IA7 & $\begin{array}{l}\text { Chief Specialist of the } \\
\text { Audit Department of } \\
\text { the Budgeting } \\
\text { Institutions of the }\end{array}$ & Kyiv City Council & Phone call/40 min & \\
\hline & & $\begin{array}{l}\text { Internal Control and } \\
\text { Audit Department }\end{array}$ & & & $\begin{array}{l}\text { Table A1.; } \\
\text { Interviewees' }\end{array}$ \\
\hline & & & & (continued) & background \\
\hline
\end{tabular}




\begin{tabular}{|c|c|c|c|c|}
\hline \# & Interviewee code & Position & Institution & Form/duration \\
\hline \multicolumn{5}{|c|}{ July-August 2021} \\
\hline 16. & IA8 & $\begin{array}{l}\text { Head of the } \\
\text { Department of } \\
\text { Planning, Budget } \\
\text { Execution, } \\
\text { Accounting and } \\
\text { Human Resources }\end{array}$ & $\begin{array}{l}\text { State Financial } \\
\text { Monitoring Service of } \\
\text { Ukraine }\end{array}$ & Meeting/40 min \\
\hline 17. & IA9 & Head of the IA sector & $\begin{array}{l}\text { Ukrainian State Film } \\
\text { Agency }\end{array}$ & Meeting/1.5 h \\
\hline 18. & IA10 & $\begin{array}{l}\text { Head of Internal } \\
\text { Audit Department }\end{array}$ & $\begin{array}{l}\text { Ministry of Ecology and } \\
\text { Natural Resources of } \\
\text { Ukraine }\end{array}$ & Meeting/40 min \\
\hline 19. & IA2 (repeated) & $\begin{array}{l}\text { Former Internal } \\
\text { Auditor }\end{array}$ & $\begin{array}{l}\text { State Service of Ukraine } \\
\text { on Drugs Control }\end{array}$ & Meeting/1 h \\
\hline 20. & IA11 & $\begin{array}{l}\text { Head of the Internal } \\
\text { Audit Department }\end{array}$ & $\begin{array}{l}\text { State Service of Maritime } \\
\text { and River Transport }\end{array}$ & Meeting/30 min \\
\hline 21. & $\begin{array}{l}\text { SAS auditor } \\
\text { (repeated) }\end{array}$ & $\begin{array}{l}\text { North Office, Head of } \\
\text { Department }\end{array}$ & $\begin{array}{l}\text { The State Audit Service of } \\
\text { Ukraine }\end{array}$ & Meeting/50 min \\
\hline 22. & SAS auditor 2 & $\begin{array}{l}\text { Head of the } \\
\text { Department for } \\
\text { Handling Complaints }\end{array}$ & $\begin{array}{l}\text { The State Audit Service of } \\
\text { Ukraine }\end{array}$ & Meeting/20 min \\
\hline 23. & IA12 & $\begin{array}{l}\text { Head of Internal } \\
\text { Audit Department }\end{array}$ & $\begin{array}{l}\text { Ministry of Youth and } \\
\text { Sports }\end{array}$ & Meeting/1 h \\
\hline 24. & IA13 & Head of the IA sector & $\begin{array}{l}\text { Ukrainian Marine and } \\
\text { River Inspection }\end{array}$ & Meeting/40 min \\
\hline 25. & IA14 & Head of the IA sector & $\begin{array}{l}\text { State Service of Ukraine } \\
\text { on Drugs Control }\end{array}$ & Meeting/30 min \\
\hline 26. & IA15 & Head of the IA sector & $\begin{array}{l}\text { The State Service } \\
\text { of Geology and } \\
\text { Mineral Resources of } \\
\text { Ukraine }\end{array}$ & Meeting/40 min \\
\hline 27. & IA16 & $\begin{array}{l}\text { Head of Internal } \\
\text { Audit Department }\end{array}$ & $\begin{array}{l}\text { State Service of Ukraine } \\
\text { on Food Safety and } \\
\text { Consumers' Protection } \\
\text { (SSFSCP) }\end{array}$ & Meeting $/ 1.5 \mathrm{~h}$ \\
\hline 28. & IA17 & Head of the IA sector & $\begin{array}{l}\text { State Service for Ethnic } \\
\text { Policy and Freedom of } \\
\text { Conscience }\end{array}$ & Meeting/1 h \\
\hline 29. & MoF specialist & $\begin{array}{l}\text { Specialist in the } \\
\text { formation of internal } \\
\text { audit policy }\end{array}$ & Ministry of Finance & Meeting/1 h \\
\hline
\end{tabular}

Table A1.

\section{About the authors}

Tamara Volodina is a $\mathrm{PhD}$ student affiliated with TRANSACT project at Nord University Business School (HHN), Norway. She holds Master degree in Business from Nord University Business School (HHN), Norway, and Taras Shevchenko National University of Kyiv, Ukraine, bilateral exchange program (a part of Norwegian-Ukrainian cooperation in Public Sector Economy Education: Accounting, Budgeting and Finance [NUPSEE]).

Giuseppe Grossi is Research Professor in accounting at Nord University, Norway, Kristianstad University, Sweden, and Kozminski University, Poland. He is also visiting professor at Tampere University, Finland. His recent publications concern hybrid organisations, smart cities, 
corruption and public budgeting. He is the Editor-in-Chief of Journal of Public Budgeting, Accounting and Financial Management, Associate Editor of Qualitative Research in Accounting and Management, guest editor and editorial board member of several accounting and public management journals. Giuseppe Grossi is the corresponding author and can be contacted at:

Changing roles of internal auditors giuseppe.grossi@hkr.se

Veronika Vakulenko is Associate Professor, PhD, at Nord University Business School, Bodø, Norway. Her research interests include public sector management; public accounting, budgeting and finance; and reforms. In addition, Veronika is interested in participatory governance, e.g. participatory budgeting and social auditing. The contextual focus of Veronika's research framed around developing countries, emerging economies or those in transition.

For instructions on how to order reprints of this article, please visit our website: 